\title{
Kalite Yönetim Ödülü Alan Otellerin Çevre Duyarlılık Faaliyetlerinin Yeşil Yıldız Kriterleri Kapsamında Değerlendirilmesi
}

\author{
Murat YURTLU ${ }^{1 *}$, Merve KAR ${ }^{2}$, , Fatoş METIN ${ }^{3(D)}$, Saniye Gül GÜNEŞ ${ }^{4}$ (D) \\ ORCID 1: 0000-0002-0947-8401 - ORCID 3: 0000-0002-3612-5679 \\ ORCID 2: 0000-0001-5736-2051 - ORCID 4: 0000-0002-5004-6504 \\ ${ }^{1}$ Iskenderun Teknik Üniversitesi, Turizm Fakültesi, Turizm Rehberliği Bölümü, 31200, İskenderun/Hatay, Türkiye. \\ 2,3 Selçuk Üniversitesi, Sosyal Bilimler Enstitüsü, Turizm İşletmeciliği Ana Bilim Dalı, 42130, Konya, Türkiye. \\ ${ }^{4}$ Selçuk Üniversitesi, Turizm Fakültesi, Rekreasyon Yönetimi Bölümü, 42130, Konya, Türkiye. \\ *e-mail: murat.yurtlu@iste.edu.tr
}

Öz

Turizmde otellerin çevreci uygulamaları daha çok desteklemesi ve misafirlerin bu konuda her geçen gün daha ilgili olmasından dolayı çevre konularında alınan sertifikalar ve ödüller önemini arttırmaktadır. Bu çalışmada Türkiye'de Kalite Yönetim Ödülünü almış olan otellerin çevre duyarlılık faaliyetlerinin Yeşil Yıldız kriterlerine göre değerlendirilmesi amaçlanmıştır. Araştırmada veriler, belirlenen otellerin internet sitelerinin içerik analizi yöntemiyle incelenmesi sonucunda elde edilmiştir. Araştırma kapsamındaki otellerin \%60'ında çevre duyarlılı bilgileri bulunmaktadır. Bu işletmelerin \%74'ünün Çevre Politikasına ve \%34'ünün Yeşil Yıldız sertifikasına sahip olduğu belirlenmiştir. İşletmelerin en fazla bilgi verdiği konular arasında Personel Eğitimi (\%68), Su Tasarrufu (\%68), Gıda Güvenliği (\%63), Elektrik Tasarrufu (\%58), Atık Yönetimi (\%58) ve Yerel Çevre ile Birlikte Hareket Etme (\%53) konularının yer aldığı saptanmıştır. Araştırmada çevre duyarlıık faaliyetlerinin bütüncül olarak ele alınarak devlet tarafından oluşturulan teşviklerle birlikte otellerin inşa ve yenileme aşamalarından işletme uygulamalarına kadar uluslararası boyutta geliştirici bir yaklaşımla sürdürülebilir kılınmasının gerekli olduğu sonucuna ulaşılmıştır.

Anahtar Kelimeler: Çevre, turizm, otel, yeşil yıldız, sürdürülebilirlik, kalite

\section{Evaluation of Environmental Awareness Activities of Hotels with Quality Management Award in the Context of Green Star Criteria}

\begin{abstract}
The importance of certificates and awards on environmental issues increases as the hotels support more environmental practices in tourism and the guests are more interested in this issue day by day. In this study, it is aimed to evaluate the environmental awareness activities of the hotels that have received the Quality Management Award in Turkey according to the Green Star criteria. The data in the research were obtained as a result of examining the websites of the selected hotels by content analysis method. According to the findings, $60 \%$ of the hotels within the scope of the research have environmental awareness information. It has been determined that $74 \%$ of these enterprises have an Environmental Policy and 34\% have a Green Star certificate. Among the topics that businesses provide the most information on, Staff Training (68\%), Water Conservation (68\%), Food Safety (63\%), Electricity Saving (58\%), Waste Management (58\%) and Acting with the Local Environment (53\%) were found to be included. In the research, it has been concluded that environmental awareness activities should
\end{abstract}

Citation/Atıf: Yurtlu, M., Kar, M., Metin, F. and Güneş, G. (2021). Kalite yönetim ödülü alan otellerin çevre duyarlılık faaliyetlerinin yeşil yıldız kriterleri kapsamında değerlendirilmesi. Journal of Architectural Sciences and Applications, 6 (2), 476-493.

DOI: https://doi.org/10.30785/mbud.972912 
be handled holistically, and with the incentives created by the state, it is necessary to make hotels sustainable with an internationally progressive approach, from the construction and renovation stages to operating practices.

Keywords: Environment, tourism, hotels, green star, sustainability, quality

\section{Giriş}

Günümüzde insanlar tarafından çevreye verilen tahribat her geçen gün artmakta ve gelinen noktada bu tahribatın sonuçlarından insanlar da etkilenmektedirler. Çevrenin korunması; yaşayan her kesimin, tüm kurum-kuruluşların ve işletmelerin sorumluluğu altındadır. Turizmin ana kaynağının doğal çevre olmasından dolayı turizm endüstrisindeki konaklama işletmeleri de çevrenin korunması gerektiği konusunda gün geçtikçe daha çok bilinçlenmektedirler. Bunun yanında bilinçli tüketicilerin artması ve yeşil pazarlama stratejilerinin yaygınlık kazanması da konaklama işletmelerinin çevreci anlayışa yönelmelerine olumlu katkı sağlamaktadır. İşletmelerin özellikle son yıllarda çevre odaklı çalışmalara ağırlık vermelerinde bu sayede devlet desteği alabilmelerinin de rolü bulunmaktadır. Turizm işletmelerinin geleceğinin büyük ölçüde çevreye bağlı olması ekolojik dengenin bozulmaya başlamasının turizm için oldukça önemli bir konu haline dönüşmesine neden olmuştur. Konaklama işletmelerinin en önemli sermayesi çevredir ve işletmelerin devamlılı̆ı çevrenin korunması ile mümkün olabilecektir. Bu bağlamda konaklama işletmelerinin çevreye duyarlı olma ve çevreyi koruma konusunda hassas olmaları gerekmektedir (Doğan ve Ertaş, 2018:218).

Turizme yönelik son 20 ila 30 yıl için genel bir değerlendirme yapıldığında gerek Covid-19 salgını öncesinde, gerek sonrasında; sürdürülebilirlik, çevre duyarlılığı, doğa koruma ve sorumlu seyahatler gibi konuların ön plana çıkan önemli konular içinde yer aldığı görülmektedir. Araştırmalar ve yapılan yayınlar da bunu doğrular niteliktedir. Kar amacı gütmeyen Hollanda'daki uluslararası bir kuruluş olan SNV Kalkınma Örgütü’nün 2009 yılında yaptığı bir araştırmada 58,5 milyon Amerikalı gezginin çevreyi koruma çabası içinde olan seyahat acentelerini daha çok tercih etme eğiliminde oldukları saptanmıştır. Dünyada en çok ziyaret edilen çevrimiçi seyahat platformu TripAdvisor internet sitesinin 2012 yılında yaptığı araştırmada ise, turistlerin yaklaşık üçte birinin (\% 30) gidecekleri destinasyonu tercih etmede öncelikli olarak çevre dostu faktörleri dikkate aldıkları belirlenmiştir. Örneğin; Orta Amerika'da yer alan Kosta Rika, çevre dostu bir geziye ilgi duyan gezginler için dünyanın en popüler destinasyonudur. 2015 yılında yapılan araştırmalarda ise, harcamalarını çevre dostu tercihler doğrultusunda gerçekleştiren ve sürdürülebilir turizm konusunda bilinçli turistlerin özellikle 2005 yılından sonra 1/3 oranında artış gösterdiği gözlenmiştir. Diğer yandan giderek daha fazla sayıda çevrimiçi rezervasyon platformları da sürdürülebilir tatilleri teşvik etmek için seyahat bilgileri vermekte, organize etmekte ve rezervasyonlarda çevre faktörlerini ön plana çıkararak seyahat acenteleri ve tur operatörleriyle ilişkilendirmektedirler (Güneş, 2020:6).

Dünyanın lider çevrimiçi seyahat acentesi Booking.com tarafından 30 ülkede 29.000'den fazla gezginden toplanan veriler ışı̆̆ında, 2021 yılında yayımlanan "Sustainable Travel Report/Sürdürülebilir Seyahat Raporu'na göre; Covid-19 salgınıyla birlikte seyahat edenlerin \%61'inin kendi sürdürülebilir seyahatlerini gerçekleştirmede istekli oldukları sonucu ortaya çıkmıştır. Rapora göre turistlerin en önemli öncelikleri sırasıyla; atıkları azaltma (\%49), gıda israfını azaltma (\%42), taksi veya kiralık araba yerine yürüyüş, bisiklete binme veya toplu taşımayı kullanma (\% 34), tek kullanımlık plastikten kaçınma (\% 33) şeklinde olurken, gezginlerin en çok endişe duydukları konular ise sırasıyla; fazla atık (\%46), yerel yaban hayatı ve doğal yaşam alanlarına yönelik tehditler (\% 38), aşırı kalabalık popüler yerler veya destinasyonlar (\% 30) ve karbondioksit emisyonları (\% 29) şeklindedir. Bunlarla beraber araştırmada, turistlerin \%84'ünün kültürel anlayışın arttırılarak kültürel mirasın korunmasını çok önemli gördüğü belirlenmiştir. Ayrıca raporda turistlerin \%76'sının turizmin ekonomik etkisinin toplumun tüm seviyelerine eşit olarak yayılmasını istediği ve \%73'ünün seyahat ederken yerel kültürü temsil eden otantik deneyimler kazanmak eğiliminde olduğu saptanmıştır. Bunlara ilave olarak ilki 2016 yılında yapılan araştırmaya göre ise, 2021 yılında sürdürülebilir bağlamda çevreye duyarlı konaklama tesislerinde konaklama niyetinde olduğunu belirten turistlerin oranı $\% 62$ 'den $\% 81$ 'e çıkmıştır (Booking.com, 2021).

Konaklama işletmeleri çevreye karşı duyarlııklarını arttırdıkça rekabet üstünlüğü elde etmektedirler (Doğan ve Ertaş, 2018:231). Bu nedenle konaklama işletmeleri çevreye duyarlı turistlere daha iyi hitap 
edebilmek adına çevre konusundaki faaliyetlerini web sayfaları aracılığıyla turistlerin bilgisine sunmaktadırlar. İşletmelerin çevreye duyarlı olmalarının sürdürülebilir turizme katkı sağlamasının yanında çevrenin korunmasına zemin hazırlamakta ve çevre bilincinin oluşmasını desteklemektedir. Türkiye'de konaklama işletmelerine Kültür ve Turizm Bakanlı̆̆ı tarafından verilen Yeşil Yıldız (Çevreye Duyarlı İşletme Belgesi) belgesi de çevreye verilen zararların en aza indirilmesini amaçlamaktadır. Bu uygulama çevre duyarlılı̆ı konusunda Türkiye'deki turizm işletmelerinde uygulanmakta olan en kapsamlı çevre uygulamalarının başında gelmektedir. İşletmelerin bu sertifikaya sahip olabilmeleri için çevre duyarlııklarını ortaya koyan çalışmalarını belgelemeleri Bakanlıkça istenmektedir.

Örgüt performanslarının bütüncül bir perspektif ile ele alınarak örgütlerin kalite yönetimi faaliyetlerindeki başarısı ve örgüt performansına etkisinin ölçülmesinde çeşitli uygulamalar gerçekleştirilmektedir. Bu noktada başarılı uygulamaların ödüllendirilerek, kalite yönetimine yönelik çabaların örgüt içerisinde oluşturduğu faydalarla birlikte görünür kılınmasına dayalı günümüzde popüler bir uygulama olan "Kalite Ödüllendirme Süreci", ilk olarak Japonya'da 1951 yılında JUSE (Japanese Union of Scientists and Engineers) tarafınca "Deming Prize" ödülü uygulamasıyla hayata geçirilmiştir. Kalite ödüllerinin öncelikli amacı, genel olarak kalite yönetimi faaliyetlerinin ve özel olarak ise Toplam Kalite Yönetimi yaklaşımlarının örgütlerde benimsenmesini, doğru şekilde uygulanmasını ve yaygınlaşmasını sağlamaktır (Samanlı, 2009:23). Türkiye turizm endüstrisinde kalite yönetimi ödülleri konusunda en popüler uygulama, GM Turizm ve Yönetim Dergisi tarafından 2006 yılında ilki gerçekleştirilen ve 2010 yılından itibaren yaklaşık 100.000 turizm profesyonelinin katılımıyla her yıl düzenlenmekte olan "Kalite Yönetim Ödülleri” (QM-Quality Management Awards)'dir. Ancak Covid-19 salgınından dolayı ödüller 2020 yılı içerisinde dağıtılamamıştır (QM Awards, 2021). Çalışmada bu noktalardan hareketle, bu çalışmanın yapıldığı 2021 yılı Nisan-Mayıs-Haziran ayı itibariyle Türkiye'de en son 2019 yılında dağıtılmış olan Kalite Yönetim Ödülünü almaya hak kazanan konaklama işletmelerinin çevre duyarlılık faaliyetlerinin Yeşil Yıldız kriterlerine göre değerlendirilmesi ve bu işletmelerdeki mevcut uygulamaların belirlenebilmesi amaçlanmıştır.

\subsection{Konaklama İşletmeleri ve Yeşil Yıldız Tesisi Simgesi (Çevreye Duyarlı Konaklama Tesisi Belgesi)}

Türkiye'de Kültür ve Turizm Bakanlığı tarafından 1993 yılından itibaren konaklama işletmelerine Çevre Dostu Kuruluş Belgesi "Çam Simgesi" verilmiştir. Söz konusu uygulama sayesinde; çevre bilincinin geliştirilmesi ile çevrenin korunması, konaklama tesislerinde çevreye duyarlı işletmecilik özelliklerinin teşvik edilmesi ve yapılaşmanın oluşturulması amaçlanmıştır. 2008 yılında ise, konaklama tesisleri için uygulanan çevreye duyarlı sınıflandırma formu geliştirilerek güncellenmiş ve ilgili işletmelere "Çevreye Duyarlı Konaklama Tesisi Belgesi / Yeşil Yıldız Tesisi Simgesi" verilmesine karar verilmiştir. Bakanlığın bir çevre duyarlııı kampanyası olan bu uygulama kapsamında; enerji verimliliğinin artırılması, su tasarrufu, çevreye zararlı maddelerin atık miktarının ve tüketiminin azaltılması, konaklama tesislerinin yatırım döneminden itibaren çevreye duyarlı biçimde planlanmaları, yenilenebilir enerji kaynak kullanımlarının teşvik edilmesi, turistik tesislerin çevreye uyumu, ekolojik mimari, çevre güzelleştirme etkinlikleri ve uygulamaları, çevre duyarlıı̆̆ konusunda bilinçlendirme ve eğitim ile bu konuda ilgili kuruluşlarla işbirliği ve Bakanlığın 1993 yılından itibaren edindiği tecrübeler, ilgili kuruluşların görüşleri ile birlikte bu konuya yönelik AB kriterleri (Eco-Label/Eko Etiket) ele alınmaktadır (T.C. Kültür ve Turizm Bakanlığı, 2021a).

Çevreye Duyarlı Konaklama Tesisi Belgesini ancak Genel Yönetim, Eğitim, Çevre Uyumu, Enerji ve Su, Kimyasallar ve Atıklar, Yiyecek-içecek ile Diğer Hizmetler ve Politikalar şeklindeki yedi temel kritere ilişkin koşulları sağlayan ve Bakanlıktan Turizm İşletmesi Belgesi bulunan konaklama tesisleri alabilmektedir. Bir konaklama işletmesinin Yeşil Yıldız tesisi simgesine (Çevreye Duyarlı Konaklama Tesisi Belgesine) sahip olabilmesi için Çizelge 1'de belirtilen asgari puanları alması gerekmektedir. 
Çizelge 1. Yeşil yıldız belgesi için alınması gereken asgari puanlar (T.C. Kültür ve Turizm Bakanlığı, 2021a)

\begin{tabular}{llll}
\hline $\begin{array}{l}\text { Tatil Tesisleri İçin Alınması } \\
\text { Gereken Asgari Puanlar }\end{array}$ & Asgari Puan & $\begin{array}{l}\text { Şehir Tesislerinin Alması } \\
\text { Gereken Asgari Puanlar }\end{array}$ & Asgari Puan \\
\hline 5 Yıldızlı Tatil Köyü & $\mathbf{3 3 0}$ & & - \\
\hline 5 Yıldızlı Otel & $\mathbf{3 0 0}$ & 5 Yıldızlı Otel & 250 \\
\hline 4 Yıldızlı Tatil Köyü & $\mathbf{2 8 0}$ & & - \\
\hline 4 Yıldızlı Otel & $\mathbf{2 3 0}$ & 4 Yıldızlı Otel & 200 \\
\hline 3 Yıldızlı Otel & $\mathbf{1 7 0}$ & 3 Yıldızlı Otel & 170 \\
\hline $\begin{array}{l}1 \text {-2 Yıldızlı Otel-Diğer } \\
\text { Konaklama Tesisleri }\end{array}$ & $\mathbf{1 4 0}$ & $\begin{array}{l}1 \text {-2 Yıldızlı Otel-Diğer } \\
\text { Konaklama Tesisleri }\end{array}$ & 140 \\
\hline
\end{tabular}

Gerekli kriterleri sağlayarak yeterli puana sahip olan tesisler Bakanlıkça denetlenerek uygun görülmesiyle birlikte tesisler için yeşil yıldız simgesini içeren ve çevreye duyarlı işletme yazısının yer aldığı bir de plaket düzenlenmektedir. Söz konusu tesisler her 2 yılda bir tekrar denetlenmekte ve asgari kriterleri sağlamaya devam etmeleri durumunda Yeşil Yıldız tesisi simgesinin süresi 2 yıl daha uzatılmaktadır (Ünlüönen, Kızanlıklı ve Arslan, 2011:448). Türkiye'de 2021 Haziran ayı itibariyle Yeşil Yıldız sertifikasına sahip toplam tesis sayısı 457'dir (T.C. Kültür ve Turizm Bakanlığı, 2021b).

Günümüzde doğal çevrenin yok olduğuna dair farkındalığın artması, çevreci hareketlerin oluşmasını sağlamış hem insanlar hem de işletmeler çevreye duyarlı faaliyetlerin gelişmesi için daha çok girişimlerde bulunmaya başlamışlardır (Mesci, 2014:92). Çevreye duyarlı yönetim anlayışını benimseyen konaklama işletmelerinin temel prensipleri, faaliyet gösterdikleri alanlardaki çevre zararlarının (atık, kimyasal, doğa tahribatı gibi) en aza indirilmesi veya bu zararların oluşmasının tamamen önüne geçilmesidir (Nemli, 2011:213). Bu bağlamda Türkiye'deki konaklama işletmelerinin bir çevre duyarlılık projesi olan Yeşil Yıldız uygulamasını iyi anlamaları ve yeterli bilgiye sahip olmaları gerekmektedir. Yeşil yıldız uygulamasının tüm konaklama işletmelerine yaygınlaştırılması sayesinde, doğal kaynakların sürdürülebilirliğinin sağlanabilmesi de mümkün olabilecektir (Cömert ve Özata Şahin, 2016:1176). Yeşil Yıldız Belgesine sahip olmanın sağladığı avantajlar; işletmelerde su ve enerji tasarrufunun sağlanarak maliyetlerin orta vadede azaltılması, çevreye zararlı maddelerin tüketiminin ve zararının azaltılması, işgücünün en uygun biçimde kullanımı, geri dönüşümlü malzeme kullanımının teşvik edilmesi, çevre ve tesisler arasındaki uyumun artması, işletmelerin yatırımlarından önce planlamalarını çevreye duyarlı yapmaları, işletmelerin pazarlama stratejilerinde avantaj sağlamaları ve çevresel duyarlılık konusunda farkındalığın artması şeklinde sıralanabilmektedir (Ünlüönen ve diğerleri, 2011).

\section{Materyal ve Yöntem}

Bu araştırmada kalite yönetim ödülü alan konaklama işletmelerinin çevre duyarlıık faaliyetlerinin yeşil yıldız kriterleri kapsamında değerlendirilmesi amaçlanmıştır. Bu amaçla araştırma kapsamında belirlenen konaklama işletmelerinin internet siteleri nitel araştırma yaklaşımlarından içerik analizi yöntemiyle incelenerek veriler elde edilmiştir. İçerik analizi, belirli miktarda materyalin sistematik, ayrıntılı ve dikkatli bir şekilde incelenerek tema, desen, varsayım ve anlamlar biçiminde yorumlanmasıdır (Berg ve Lune, 2019:344). Bu doğrultuda; araştırma kapsamında ele alınan konaklama işletmelerinin internet sitelerinde 2021 yılı Nisan, Mayıs ve Haziran aylarında detaylı tarama modeliyle incelemeler gerçekleştirilmiştir.

\subsection{Araştırma Evreni ve Örneklem}

Araştırma alanı veya evreni seçilirken belirli bir bölge veya sınırlı bir alanda yapılan çalışmalar genelde sadece araştırma evrenini konu alan örneklemin bulunduğu çevredeki sonuçları ortaya koyabilmektedir. Bu bağlamda nitel desene sahip birçok araştırmanın geçerlik, güvenirlik, tutarlık ve inandırıcılığı hatalı örnek seçimi veya yöntem sonucunda sorunlu olabilmektedir (Baltacı, 2018:231). Bu sebeple veri toplama için seçilen araştırma evreninin ortaya çıkaracağı sonuçların evrensel olması 
önem arz etmektedir. Çalışmada araştırma evreni olarak Türkiye'deki turistik konaklama işletmeleri seçilmiştir. Türkiye, Dünya Turizm Örgütü'nün (UNWTO) yayımladığı "International Tourism Highlights" raporunda dünya genelinde ziyaret edilen ilk on destinasyon içinde altıncı sırada yer almaktadır (UNWTO, 2021). Ayrıca 2019 yılında gerçekleşen Dünya Turizm Forumunda Fransa eski Cumhurbaşkanı Hollande, Türkiye otelcilik sektörünün dünyadaki en iyi örnekler arasında olduğunu vurgulamıştır (Yurtlu, 2021:55). Bu gelişmeler Türkiye'nin turizm ve otelcilikte dünya genelinde söz sahibi ülkeler arasında olduğunu göstermektedir. Buna bağlı olarak Türkiye otelcilik sektöründe uygulanan faaliyetlerin evrensel özellikler taşıdığı söylenebilir.

Araştırma kapsamında Türkiye'de faaliyet gösteren konaklama işletmeleri araştırma evreni olarak belirlenmiştir. Kalite ödüllerinin genelde ülke ekonomileri, özelde ise işletmeler bazında performans arttırmada en etkili itici güçlerden biri olduğu bilinmektedir (Beşkese, 2001). Bu konuda işletmeler üzerinde yapılan araştırmalarda ödül kazanan firmaların faaliyet performanslarının artarak geliştiği tespit edilmiştir (Corredor ve Goni, 2010). Türkiye'de yaklaşık 10 yıldır verilen QM Kalite Yönetim Ödülleri; sektör profesyonelleri tarafından Türkiye turizm endüstrisindeki yerli firmalara verilen en kapsamlı turizm ödülleri olarak kabul görmektedir. Covid-19 salgını sebebiyle 2020 yılı ödülleri bu araştırmanın yapıldığı 2021 yılı Haziran ayı itibariyle henüz verilmediğinden, en son 2019 yılı QM Kalite Yönetim Ödülleri (Quality Management Awards) çerçevesinde ödül alan 32 konaklama işletmesi bu çalışmanın araştırma örneklemi olarak seçilmiştir (QM Awards, 2019). 2019 yılı QM Kalite Yönetim Ödüllerine internet üzerinden 105.254 kişi katılım göstermiş ve toplam 9 dalda, 65 kategoride ödüller verilmiştir. Ödüller çerçevesinde konaklama işletmeleri türlerine göre; "En İyi Yönetilen Animasyon ve Eğlence, Etkinlik, Çocuk Etkinlik, Küçük ve Butik, Muhafazakâr, Mice, Mice Luxury, Spa \& Wellness, Thermal, Kayak ve Golf Otelleri" ve bölgelerine göre; "En İyi Yönetilen Aile, Şehir ve Resort Otelleri" kategorilerinde ödüllerini almışlardır (QM Awards, 2019). Ödül alan konaklama işletmelerinin faaliyette bulundukları bölgeler incelendiğinde, Türkiye'nin yedi farklı coğrafi bölgesinden konaklama işletmelerinin yer aldığı görülmektedir. Bu bağlamda araştırma kapsamında belirlenen konaklama işletmelerindeki çevre duyarlıık faaliyetlerine ilişkin uygulamaların Türkiye'nin genelini temsil ettiği söylenebilir.

\subsection{Araştırma Geçerliği ve Güvenirliği}

Nitel araştırma yaklaşımlarında geçerliği sağlamak için araştırmacı veya araştırmacıların veri toplama aşamasında kendilerinin yer alması, araştırma tekniği ve verilerin analizi sürecinde detaylı bilgilerin sunulması, araştırma modelinin oluşturulmasında araştırmacılar içerisinde tartışmaların yapılması, doküman incelemelerinin en az iki araştırmacıyla sürdürülmesi ve ham verilerin doğasına sadık kalınarak doğrudan sunulması gerekmektedir (Yıldııım ve Şimşek, 2011). Bu araştırmada, çalışmanın aşamaları açıkça ortaya konmaya çalışımıştır. Bu bağlamda araştırma yaklaşımı, evren ve örneklem seçimi, veri analiz tekniği, veri analizi süreci ve araştırma bulguları sunulmuştur. Araştırma kapsamındaki konaklama işletmelerinin internet siteleri, araştırmacıların ortak uzlaşıyla seçilen yeşil yıldız temel kriterleri esas alınarak ayrı ayrı incelenmiştir.

Araştırmanın güvenirliğine ilişkin olarak "araştırmacı üçgenlemesi tekniği" uygulanmıştır. Araştırmacı üçgenlemesi tekniği, araştırmada elde edilen nitel verilerin birbirlerinden bağımsız bir biçimde iki ya da daha çok sayıdaki araştırmacı tarafından analiz edilerek karşılaştırılmasıdır (Patton, 2014). Araştırma sürecinde işletmelerin internet sitelerinden elde edilen veriler, üç araştırmacı tarafından karşılaştırılarak verilerin doğruluğu kontrol edilmiştir. Verilerin karşılaştırılmasında ortaya çıkan görüş ayrılıkları üzerinde tartışılarak yeniden düzenlemeler yapılmıştır. Kontrol sonucu elde edilen verilerin son hali ise bir uzman akademisyenin görüşüne sunulmuştur. Araştırma sürecine ilişkin her aşamada araştırmacılar arasında tartışmalar gerçekleştirilerek uzlaşı oluşturulmuş ve böylelikle çalışmanın geçerliği ve güvenirliği sağlanmaya çalışılmıştır.

\subsection{Araştırma Soruları}

2019 yılında QM Kalite Yönetim Ödülü alan toplam 32 konaklama işletmesinin yeşil yıldız kriterleri kapsamında çevre duyarlılık faaliyetlerinin neler olduğunun belirlenebilmesine ilişkin gerçekleştirilen bu araştırmanın üç temel sorusu aşağıda yer almaktadır: 
a) QM Kalite Yönetim Ödülü alan konaklama işletmelerinin profil bilgileri ve web sitelerindeki çevre duyarlılık faaliyetleri nasıl bir dağılım göstermektedir?

b) QM Kalite Yönetim Ödülü alan konaklama işletmelerinin çevre duyarlılık kapsamında sahip oldukları sertifika ve ödüller nelerdir?

c) QM Kalite Yönetim Ödülüne sahip konaklama işletmelerinin web sitelerindeki çevre duyarlılık bilgileri ve uygulamaları nelerdir?

\subsection{Verilerin Analizi}

Çalışmada araştırma örneklemi olarak belirlenen konaklama işletmelerinin internet sitelerinden doküman incelemesiyle elde edilen veriler içerik analizi tekniğiyle çözümlenerek betimlenmiştir. Doküman incelemesi araştırılması amaçlanan konu ve olaylar hakkındaki bilgilerden oluşan yazıı materyallerin analizidir (Yıldırım ve Şimşek, 2011:187). İçerik analizi ise, birbirlerine benzeyen verilerin belirli kavramlar ve kategoriler kapsamında gruplandırılması ve daha kolay anlaşılır hale getirilerek yorumlanmasıdır (Yıldırım ve Şimşek, 2011:227). Bu doğrultuda araştırma kapsamında örneklem dahilindeki konaklama işletmelerinin internet sitelerinden elde edilen veriler, yeşil yıldız kriterleri esas alınarak içerik analiziyle çözümlenmiştir. Analizi yapılan toplam 32 konaklama işletmesine analiz öncesinde 1'den 32'ye kadar Otel ${ }_{1}$, Otel $_{2}, \ldots$, Otel $_{32}$ şeklinde kodlama yapılımıştır. Araştırma kapsamında elde edilen veriler 2017 yıında Ertaş ve arkadaşlarının yeşil yıldızlı tesisler üzerinde yedi tema ve 12 kategoride yaptıkları içerik analizi çalışmasıyla karşılaştırılmıştır (Ertaş, Kırlar, Yeşilyurt ve Koçak, 2017). ilgili araştırmada yeşil yıldız kriterlerini oluşturan temel başlıkların, araştırma temasının oluşturulmasında etken olduğu belirlenmiştir. Bunun neticesinde ilgili araştırmada ortaya çıkan yedi tema üzerinde bu araştırmadaki araştırmacılar arasında da uzlaşı sağlanmıştır. Ancak temaları oluşturan kategorilerin sayısı bu araştırmada daha fazla oluşmuştur. Bu çalışmada yapılan içerik analizinde yedi tema ve 33 kategori elde edilmiştir. Bu temalar ve kategoriler araştırmanın bulgular bölümünde Çizelge 3'de sunulmaktadır. Ayrıca verilerin frekans (f) ve yüzde (\%) değerleri açık ve sistematik bir şekilde çizelgelerde gösterilmiştir. Buna ilave olarak gerekli yerlerde doğrudan alıntılarla veriler desteklenmiş ve betimlenerek verilerin analizi gerçekleştirilmiştir.

Araştırmada örneklem dahilinde, incelemeye alınan 32 konaklama işletmesinden iki işletmenin (Otel ${ }_{4}$ ve Otel ${ }_{15}$ ) web sitesine ulaşılamamıştır. İlgili otel işletmelerinin adı farklı arama motorlarında taranmasına rağmen arama sonuçlarında tesislerin adına ilişkin herhangi bir bulguya rastlanılamamıştır. Ancak arama motorlarının ilgili tesisleri benzer isimde olan sonuçlarda öncelikli olarak sunmakta olduğu görülmüştür. Bu karşılaşan siteler, ilgili tesislerin web adresinin uzantısının "....com" yerine "....net" şeklinde biten ve farklı işletmeler tarafından oluşturulan yaprak siteleridir. Bu işletmelerin web sitelerine ulaşılamamasının sebebi olarak, bu araştırma sürecinde işletmelerin el değiştirmesinden kaynaklandığı düşünülmektedir. Diğer taraftan işletmeler web sitelerinde sunmadıkları çeşitli çevre uygulamalarını da gerçekleştirebilmektedirler. Bu çalışma kapsamında konaklama işletmelerinden elde edilen bilgiler sadece işletmelerin internet siteleriyle sınırlı kalmıştır.

\section{Bulgular ve Tartışma}

Araştırma kapsamında incelenen QM Kalite Yönetim Ödülü alan toplam 32 konaklama işletmesine ilişkin genel bilgiler Çizelge 2'de sunulmaktadır. 
Çizelge 2. QM kalite yönetim ödülüne sahip konaklama işletmelerine ilişkin genel bilgiler

\begin{tabular}{|c|c|c|c|c|c|}
\hline Tesis Sınıfı & $\mathbf{F}$ & $\% *$ & Yer & $f$ & \%* \\
\hline 5 Yıldızlı & 29 & 91 & Antalya & 17 & 53 \\
\hline 4 Yıldızlı & 2 & 6 & İzmir & 3 & 9 \\
\hline \multirow{2}{*}{ Butik Otel } & \multirow{2}{*}{1} & \multirow{2}{*}{3} & Kıbrıs & 3 & 9 \\
\hline & & & Muğla & 2 & 6 \\
\hline Toplam & 32 & 100 & İstanbul & 1 & 3 \\
\hline \multirow{2}{*}{ Otel Türü } & & & Ankara & 1 & 3 \\
\hline & & & Diğer iller** & 5 & 17 \\
\hline Resort & 26 & 81 & Toplam & 32 & 100 \\
\hline Şehir & 6 & 19 & \multicolumn{2}{|l|}{ Çevre Duyarlılık Bilgisi } & \\
\hline Toplam & 32 & 100 & Var & 19 & 60 \\
\hline Mülkiyet Türü & & & Yok & 7 & 22 \\
\hline Zincir & 23 & 72 & $\begin{array}{l}\text { Sadece ödül, logo \& } \\
\text { sertifika bilgisi }\end{array}$ & 4 & 12 \\
\hline \multirow[t]{2}{*}{ Bağımsız } & \multirow[t]{2}{*}{9} & \multirow[t]{2}{*}{28} & $\begin{array}{l}\text { Web sitesine } \\
\text { ulaşılamayan }\end{array}$ & 2 & 6 \\
\hline & & & Toplam & 32 & 100 \\
\hline Toplam & 32 & 100 & $\begin{array}{l}\text { Sürdürülebilirlik } \\
\text { Raporu }\end{array}$ & 11 & 34 \\
\hline
\end{tabular}

*: Çizelgedeki yüzdelik veriler yuvarlanmıştır. **: Afyon, Bolu, Gaziantep, Malatya, Ordu

Çizelge 2'de araştırma kapsamındaki konaklama işletmelerinin çoğunluğunun 5 yıldızlı (\%91), resort (\%81) ve zincir (\%72) işletmelerden oluştuğu görülmektedir. Bu işletmelerin yarısından fazlası (\%53) Antalya'da bulunmaktadır. İnternet sitelerinde çevre duyarlılık bilgisine sahip işletme sayısı \%60 oranla 19 'dur. 7 işletmenin internet sitesinde çevre duyarlılık bilgisi bulunmazken, 4 işletmenin web sitelerinde sadece ödül, logo ve sertifika bilgilerine yer verdiği saptanmıştır. Ayrıca iki işletmenin web sitesine ulaşılamamıştır. Bu nedenlerle araştırmada çevre duyarlılık faaliyetleri açısından içerik analizi 19 işletmenin (\%60) internet sitesi üzerinden yapılabilmiştir.

Internet sitesinde çevre duyarlılık bilgisine sahip 19 işletmeden üçü bağımsız (Otel ${ }_{3}$, Otel $_{8}$, Otel $_{14}$ ) geriye kalan 16 işletme zincir işletmelerdendir. Ayrıca bu işletmeler içerisindeki 11 işletmenin (\%34) internet sitesinde, çevre duyarlıık bilgilerine ilişkin sürdürülebilirlik raporlarına da ulaşıımıştır $\left(\right.$ Otel $_{6}$, Otel $\left.\right|_{8}$, Otel $_{10}$, Otel $_{11}$, Otel $_{12}$, Otel $_{17}$, Otel $_{23}$, Otel $_{27}$, Otel $_{30}$, Otel $_{31}$, Otel $\left._{32}\right)$. Sürdürülebilirlik raporuna sahip otellerden ise, sadece Otel $_{8}$ bağımsız bir işletme olup diğer on tesis, zincir işletmelerdendir. Sürdürülebilirlik raporu, işletmelerin performanslarını ölçerek değişimlerini yönetebilmelerine yardımcı olmakta, faaliyetlerini daha sürdürülebilir hale getirmede fayda sağlamakta ve çevre, toplum ve ekonomi üzerindeki etkilerine yönelik bilgiler taşımaktadır (Ekergil ve Özgür Göde, 2017:860). Araştırmada analiz edilen sürdürülebilirlik raporlarında işletmelerin daha kurumsal bir biçimde çevre duyarlıık faaliyetlerine ilişkin çevre faaliyetleri, eğitimler, atık yönetimi ve kimyasal kullanımına yönelik detaylı bilgiler ve tablolar halinde su ve enerji tüketim verileri gibi veriler yer almaktadır. Ancak ulaşılan sürdürülebilirlik raporlarının geneline ilişkin olarak en güncel raporların 2020 yılında ilgili işletmelerce web sitelerinde yayımlandığı ve bilgilerin 2019 ve daha önceki yıllara ait verilerden oluştuğu gözlenmiştir.

Konaklama işletmelerinin elde ettiği ödül ve sertifikalar tanıtım ve pazarlamalarında rekabet üstünlüğü sağlamaktadır (Turizm Gazetesi, 2021). Araştırmada incelenen konaklama işletmelerinin \%72'sinin web sitelerinde ödül, logo ve sertifika bilgilerine yer verdiği belirlenmiştir. Bu bağlamda Çizelge 3 'de analizi yapılan konaklama işletmelerinin internet sitelerinde sundukları ödül, logo ve sertifikalar yer almaktadır. 
Çizelge 3. QM kalite yönetim ödülüne sahip konaklama işletmelerinin internet sitelerindeki ödül, logo ve sertifikalar

\begin{tabular}{lll} 
Ödül ve Sertifikalar & $\mathbf{f}$ & $\%$ \\
\hline Güvenli (Safe) Turizm Sertifikası & 16 & 50 \\
\hline Yeşil Yıldız & 11 & 34 \\
\hline Mavi Bayrak & 11 & 34 \\
\hline ISO-EN 22000 (Gıda Güvenliği Yönetim Sistemi Belgesi) & 8 & 25 \\
\hline ISO-EN 14001 (Çevre Yönetim Sistemi Belgesi) & 7 & 22 \\
\hline ISO-EN 9001 (Kalite Yönetim Sistemi Belgesi) & 7 & 22 \\
\hline TRIPADVISOR Mükemmellik Sertifikası & 6 & 19 \\
\hline Travelife & 3 & 9 \\
\hline Beyaz Bayrak (Gıda Güvenliği) & 3 & 9 \\
\hline TUI (Hayvan Dostu Otel) & 2 & 6 \\
\hline TUI (Çevre Duyarlılı̆ı) & 2 & 6 \\
\hline Beyaz Yıldız & 2 & 6 \\
\hline iSG-OHSAS 18001 (İ̧̧ Sağlığı ve Güvenliği Yönetim Sistemi Belgesi) & 2 & 6 \\
\hline Thomas Cook (Kanıtlanmış Kalite Ödülü) & 2 & 6 \\
\hline Green Gold (Leed Doğa Dostu Sertifika) & 2 & 6 \\
\hline Diğer* & 8 & 25 \\
\hline Toplam İşletme Sayısı & 32 &
\end{tabular}

*Diğer: Anadolu Markaları-Turizm Birincisi, Çevreyle Dost Otel Sertifikası, Türkiye'nin En lyi Kıyı Otelleri Birincisi, En Iyi Turizm Yatırımı Ödülü, Gastronomy İstanbul Ödülleri, Top Hotels-Kusursuz Konaklama Ödülü, Otel Puan Özel Ödülü, Üstün Lezzet Ödülü, ETS Yüksek Misafir Memnuniyeti Ödülü, Otelz Müşteri Memnuniyeti Ödülü, En Memnun Kalınan Tesis Ödülü, Coral Travel Starway Ödülü, Booking.com Yorum Ödülü, Hotels.com Misafir Derecelendirme Ödülü, World Luxury Spa Ödülü, TripExpert Uzman Görüşü Ödülü, Yeşil Anahtar Sertifikası, Helal Turizm Sertifikası, Sıfır Atık Belgesi.

Kültür ve Turizm Bakanlığı web sitesinden 2021 yılı Haziran ayında "Yeşil Yıldızlı Tesisler" listesi temin edilerek incelenmiştir (T.C. Kültür ve Turizm Bakanlı̆̆ı, 2021b). Buna göre listede yer alan 457 tesisten araştırma kapsamında incelemeye alınan 32 konaklama işletmesinden 21 tanesinin yeşil yıldızlı tesisler içerisinde olduğu saptanmıştır. Ancak bu tesislerden sadece 11 tanesinin yeşil yıldız sertifika veya logosunu web sitesinde bulundurduğu görülmektedir. Analizi yapılan konaklama işletmelerinin genelinin çevre duyarlılık kapsamında ödül, logo ve sertifikalara ilişkin bilgiler vermesinin yanında bu belgelerin çok çeşitli ödül ve sertifikalardan oluştuğu belirlenmiştir. Örneğin işletmelerin farklı tur operatörü ve seyahat acentelerinden veya çeşitli yarışmalardan aldıkları ödül ve sertifikaları web sitelerinde paylaştıkları gözlenmiştir. İşletmelerin web sitelerinde rastlanan bu denli farklı ödül ve sertifikalara yer veriyor olmaları rekabet üstünlüğü kurabilme stratejileriyle açıklanabilir. Ayrıca 2020 yılı Nisan ayında Covid-19 sürecinde ülkemizde yürürlüğe giren ve dünyada ilk olma özelliği taşıyan "Güvenli Turizm Sertifikası" uygulamasına da araştırma kapsamındaki işletmelerin yarısının kısa sürede reaksiyon göstererek temin ettiği ve bu sertifikayı da web sitelerinde sundukları belirlenmiştir.

Araştırma kapsamında 2019 yılı QM Kalite Yönetim Ödülüne sahip konaklama işletmelerinden \% 60'nın (19 işletme) internet sitelerinde çevre duyarlılık bilgilerine yer verdikleri saptanmıştır. Bu işletmelerin çevre duyarlılık bilgileri, yeşil yıldız kriterleri esas alınarak oluşturulan yedi tema başlığı altında incelenmiştir. Bu temalar; Genel Yönetim, Eğitim, Çevre Uyumu, Enerji ve Su, Kimyasallar ve Atıklar, Yiyecek-içecek ile Diğer Hizmetler ve Politikalar şeklindedir. Araştırmacılar tarafından yapılan içerik analizine göre bu yedi tema altında ortaya çıkan alt kategorilere ilişkin bilgiler ve uygulamalar Çizelge 4 'de sunulmaktadır. 
Çizelge 4. QM Kalite Yönetim Ödülü Alan Konaklama İşletmelerinin İnternet Sitelerinde Yer Alan Çevre Duyarlılık Bilgileri ve Uygulamaları

\begin{tabular}{|c|c|c|c|c|c|}
\hline Genel Yönetim & $f$ & $\%$ & Enerji ve Su & $\mathrm{f}$ & $\%$ \\
\hline Çevre Politikası & 14 & 74 & Su Tasarrufu & 13 & 68 \\
\hline $\begin{array}{l}\text { Yerel Çevre ile } \quad \text { Birlikte } \\
\text { Hareket Etme }\end{array}$ & 10 & 53 & Elektrik Tasarrufu & 11 & 58 \\
\hline Etkinlikler & 9 & 47 & Yenilenebilir Enerji Kaynağı Kullanımı & 5 & 26 \\
\hline Eğitim & & & Doğal Gaz Tasarrufu & 4 & 21 \\
\hline Personel Eğitimi & 13 & 68 & Kimyasallar ve Atıklar & & \\
\hline Misafir Eğitimi & 5 & 26 & Atık Yönetimi & 11 & 58 \\
\hline \multirow{2}{*}{$\begin{array}{l}\text { Tedarikçilerle } \\
\text { Eğitim }\end{array}$} & \multirow{2}{*}{4} & \multirow{2}{*}{21} & Atıkların Değerlendirilmesi & 6 & 32 \\
\hline & & & Kimyasalların Azaltılması & 6 & 32 \\
\hline Çevre Uyumu & & & Hava Emisyon Kontrolü & 5 & 26 \\
\hline \multirow{2}{*}{ Ekolojik Çevre } & \multirow{2}{*}{9} & \multirow{2}{*}{47} & Yiyecek-içecek & & \\
\hline & & & Gıda Güvenliği & 12 & 63 \\
\hline \multirow{2}{*}{ Ekolojik Sarf Malzemeleri } & \multirow{2}{*}{7} & \multirow{2}{*}{37} & Yiyecek İçecek Tasarrufu & 7 & 37 \\
\hline & & & Organik Ürün Sunma & 5 & 26 \\
\hline \multirow{2}{*}{ Ekolojik Mimari } & \multirow{2}{*}{4} & \multirow{2}{*}{21} & İşletme İçi Organik Üretim & 4 & 21 \\
\hline & & & Gıda Analiz Laboratuvarı & 1 & 5 \\
\hline \multicolumn{6}{|l|}{ Diğer Hizmetler ve Politikalar } \\
\hline \multicolumn{4}{|l|}{ Çocuk Hakları Politikası } & 9 & 47 \\
\hline \multicolumn{4}{|l|}{ Covid-19 Politikası } & 8 & 42 \\
\hline \multicolumn{4}{|l|}{ Kalite Politikası } & 7 & 37 \\
\hline \multicolumn{4}{|l|}{ Sosyal Sorumluluk Politikası } & 7 & 37 \\
\hline \multicolumn{4}{|l|}{ Bisiklet Dostu İşletme } & 4 & 21 \\
\hline \multicolumn{4}{|l|}{ Yöresel Farkındalık Politikası } & 4 & 21 \\
\hline \multicolumn{4}{|c|}{ Tarihi ve Kültürel Kaynakların Korunması ve Tanıtımı Politikaları } & 4 & 21 \\
\hline \multicolumn{4}{|l|}{ Kadın Hakları ve Eşitlik Politikası } & 3 & 16 \\
\hline \multicolumn{4}{|l|}{ Dijitalleşme Politikası } & 3 & 16 \\
\hline \multicolumn{4}{|l|}{ Entegre Yönetim Politikası } & 2 & 11 \\
\hline \multicolumn{4}{|l|}{ Kurumsal İletişim Politikası } & 2 & 11 \\
\hline \multicolumn{4}{|l|}{ Toplam İşletme Sayısı } & 19 & \\
\hline
\end{tabular}

Araştırma kapsamındaki çevre duyarlılık bilgilerine sahip ödüllü işletmelerin web siteleri incelendiğinde, en fazla çevre politikasına (\%74) yönelik bilgilere yer verildiği belirlenmiştir. Çevre duyarlıık bilgileri çerçevesinde işletmelerin \%50'sinden fazlasının web sitelerinde paylaştıkları diğer bilgi ve uygulamalar ise sırasıyla; personel eğitimi (\%68), su tasarrufu (\%68), gıda güvenliği (\%63), elektrik tasarrufu (\%58) ve yerel halk ile birlikte hareket etme (\%53) şeklindedir. ilgili işletmelerin çevre duyarlılık bilgilerine ilişkin \% 50'nin altında kalan oranlardaki temel bilgi ve uygulamalarının dağılımı ise sırasıyla; çevre etkinlikleri (\% 47), ekolojik çevre bilgileri (\% 47), atık yönetimi (\% 42), ekolojik sarf malzemeleri (\% 37), yiyecek-içecek tasarrufu (\% 37), atıkların değerlendirilmesi (\% 32), kimyasalların azaltılması (\% 32), misafir eğitimi (\% 26), yenilenebilir enerji kaynağı kullanımı (\% 26), hava emisyon kontrolü (\% 26), organik ürün sunma (\% 26), tedarikçilerle etkileşimli eğitim (\% 21), ekolojik mimari (\% 21), doğal gaz tasarrufu (\% 21) ve işletme içi organik üretim (\% 21) şeklindedir. Ayrıca bir işletmenin işletme bünyesinde gıda analiz laboratuvarı bulunmaktadır. Bunların yanında işletmelerin diğer hizmet ve politikaları çerçevesinde en fazla çocuk hakları politikası (\%47) hakkında bilgilere yer verdikleri gözlenmiştir. Bu politikayı sırasıyla Covid-19 (\%42), kalite (\%37) ve sosyal sosyal sorumluluk politikaları (\%37) takip etmiş̧ir.

\subsection{Genel Yönetim Temasına Yönelik Uygulamalar}

Genel yönetim teması altında işletmelerin çevre politikalarının bulunması ve bu politikalar çerçevesinde eylem planlarının hazırlanarak uygulanması gerekmektedir. İşletmelerin bu konuda işletme içinde uygulama yapacak özel bir yetkili bulundurması ya da ilgili hizmetin bir uzman firma aracılı̆̆ıyla alınması gerekmektedir (T.C. Kültür ve Turizm Bakanlığı, 2017:4). Çevre politikaları elektrik, su, doğal gaz tüketimine yönelik tasarruf yapma, atık ve kimyasal miktarı takibi, verilerin toplanması ve raporlama, uluslararası düzeyde kabul gören çevre yönetim belgelerine sahip olma, çevre konusunda 
yerel yönetim ve yöredeki diğer tesislerle ortak hareket etme ve çevre konusunda organizasyonlara katılma ve etkinlikler düzenleme gibi bir dizi eylem planı ve hedeflerden oluşmaktadır. Araştırmada çevre duyarlılık bilgileri kapsamında incelemeye alınan işletmelerin çoğunun genel yönetim çerçevesinde çevre politikaları hakkında bilgiler verdiği belirlenmiştir. Bu bilgilere ilişkin örnekler aşağıda sunulmaktadır.

"Gerçekleştirdiğimiz tüm faaliyetlerimizde çevreye olabilecek etkileri öngörmeyi ve ilgili önlemleri almayı, çevre bilincini artırmayı, çevre dengesi ve biyolojik çeşitliliği korumayı; tüm bu faaliyetlerimizi belirlenen hedefler doğrultusunda gerçekleştirirken sürekli iyileştirmeyi, çalışanların düzenli olarak eğitilmesini, ilgili ulusal yasal zorunluluklar ve uluslararası gereklilikleri yerine getirmeyi, iş güvenliği risklerinin azaltılması ile çalışan ve çalışan temsilcilerinin danışma ve katılımının sağlanmasını, bulunduğumuz bölgelerde ortak faydalar sağlamayı taahhüt ediyoruz." (Otel ${ }_{1}$ )

“"Doğa Dostu” yalnızca bir slogan değildir. Bir hedef tanımıdır. Yenilikçi doğa dostu programlarımız ve girişimlerimiz, çevremizi korumak ve Türkiye'nin vazgeçilmez doğal kaynakları üzerindeki etkimizi en aza indirgemek için tasarlanmıştır. Gündelik işletme kültürümüz, sorumlu ve sürdürülebilir felsefelerden etkilenmektedir. Çevreyi korumak ve sürdürülebilir turizmin gerekliliğini sağlamak amacıyla, çevreye olan etkilerimizi tespit eder, olumsuz etkileri, olası tehlikeleri ve atıklarımızı kontrol altına alırız. Doğal kaynakların kullanımını, enerji tüketimini, hava, su ve toprak kirlenmesini en aza indirgemek için gayret ederiz." (Otel $\left.{ }_{3}\right)$

"Faaliyet gösterdiğimiz çevredeki ekosistemin, biyoçeşitliliğin, kültürel değerlerin ve yerel üreticilerin korunmasına karşı sorumluluk duyuyoruz. Gelecek nesiller için daha iyi bir dünya bırakmaya çalışıyoruz. Tedarikçi seçimlerinde ISO 14001 Çevre Yönetim Sistemi belgesi olması ve gıda tedarikçilerimizin ISO 22000 Gıda Güvenliği Yönetim Sistemi belgesi olması tercih önceliğimizdir. Satın alımlarımızın tamamını yakın bölgelerden yapıyoruz. Böylece tedarikçi firmaların teslimat araçlarının $\mathrm{CO}_{2}$ salınımlarını minimize ederek çevreye yapılan etkilerin azaltılmasını hedefliyor ve bölgemiz firmalarını destekliyoruz. Enerji ve su tasarrufu için çalışanlarımızı eğitiyoruz. Geri dönüşüm için atık yönetimi uyguluyoruz. Atık su yönetimi uyguluyoruz." (Otel $\left.{ }_{11}\right)$

Araştırma kapsamındaki internet sitelerinde çevre duyarlılık bilgisine sahip işletmelerin \%50'sinden fazlasının çevre politikalarında yerel çevre ile birlikte hareket ettikleri gözlenmiştir. Burada işletmeler çevreye yönelik uygulamalarında yerel halk ve yerel kuruluşları amaç ve hedefleri doğrultusunda faaliyetlerine dahil etmektedirler. Otel ${ }_{32}$, işletme içinde yaptığı çevre etkinlikleri dışında yerel kuruluşlar ile beraber ağaç dikme etkinliği, çevre yürüyüşleri ve plaj etkinlikleri ile bölge halkını da bilinçlendirme çalışmalarına dahil etmektedir. Otel $_{8}$, çevre faaliyetleri çerçevesinde çevre etkilerini belirleyerek kirliliği en az seviyeye indirmeyi, enerji verimliliği faaliyetlerini desteklemeyi, sürdürülebilir turizmi benimseyerek ekosistemlerin ve biyoçeşitliliğin korunmasını sağlamayı, yerel toplumu ve tüm paydaşlarını da bu yönde desteklemeyi amaç edinmiştir. Otel ${ }_{1}$ ve Otel ${ }_{2}$, çevre programıyla karar alma süreçlerinde misafirleri dikkate almayı, çalışanlarına destek olmayı, iş ortaklarılla birlikte inovasyon yapmayı ve yerel halk ile birlikte hareket etmeyi stratejik amaçları olarak belirlemiştir.

Çevre konusunda yapılan etkinliklerde işletmeler; doğal yaşamı destek projeleri oluşturmakta ve uygulamaktadır. Buna bağı olarak çevre bilincini arttırıcı faaliyetler düzenlemekte, misafirleri adına ağaçlar dikmekte, hatıra ormanları oluşturmakta, çevrelerinde temizlik uygulamaları yapmakta, aktif çevre koruma uygulamalarının yanında insana önem veren faaliyetler sürdürmektedirler. Bu kapsamda işletmelerin düzenledikleri etkinliklere örnek olarak; Otel ${ }_{6}$, Otel $_{8}$, Otel $_{12}$ ve Otel ${ }_{30}$; ihtiyaç sahiplerine yardım projeleri, köy okullarına destek projeleri, doğal yaşamı destek projeleri gibi projelerde yıl içerisinde düzenli olarak yer almakta veya projeleri üstlenmektedirler. Ayrıca Otel ${ }_{8}$, insan ve çevre temalı fotoğraf sergileri düzenleyerek yöre halkı, öğrenciler ile diğer ülke halklarına yönelik çevresindeki kuş, bitki ve diğer canlıların tanıtılması ve korunması çalışmaları yapmaktadır. Otel ${ }_{11}$, çocuk kulübünde doğayı tanıtıcı ve çevre bilincini geliştirici faaliyetler düzenlemekte ve misafirler adına "Hatıra Ormanında" ağaçlar yetiştirmektedir. Otel ${ }_{6}$, Otel ${ }_{12}$ ve Otel $_{30}$, belirli periyodlarda çam dikimi 
etkinlikleri düzenlemektedir. Otel ${ }_{32}$, çalışanları ve misafirleri ile birlikte "Çevre iç̧in 15 Dakika" etkinlikleri ile çevrede mıntıka temizliği yapmaktadır. Otel ${ }_{10}$, Otel ${ }_{14}$ ve Otel ${ }_{16}$, geleneksel aktif çevre koruma çalışmalarının yanında insana önem veren faaliyetlerde bulunmaktadır. Otel ${ }_{23}$, misafirlerini bisiklet kullanmaya teşvik ederek karbon ayak izini azaltmada katkı sağlamakta, oluşturduğu koşu ekipleriyle yarışmalara katılarak çevre duyarlılık kapsamında karbon salınımına dikkat çekmekte ve sivil toplum kuruluşlarına bağış organizasyonları düzenlemektedir.

\subsection{Eğitim Temasına Yönelik Uygulamalar}

Yeşil yıldız kriterleri çerçevesinde eğitim teması altında işletmeler tarafından çevre bilincinin arttırılmasında çevresel önlemlerin ve eylem planlarının uygulanmasına ilişkin personele, misafirlere ve çocuk misafirlere yönelik periyodik eğitim faaliyetleri bulunmaktadır (T.C. Kültür ve Turizm Bakanlığı, 2017:5). Araştırmada incelemeye alınan işletmelerin bu doğrultuda misafir, personel ve tedarikçilerle etkileşimli eğitim faaliyetlerinde bulundukları saptanmıştır. İşletmelerin en fazla personel eğitimi hakkında bilgi verdikleri ve bunu misafir ve tedarikçilerle olan eğitimlerin izlediği belirlenmiştir. Otel ${ }_{11}$, çalışanlarını ve misafirlerini çevreye karşı duyarlı olmaları konusunda teşvik etmekte, daha az enerji tüketimi için misafirlerini bilgilendirerek yönlendirmekte ve çocuk kulübünde çocuklarla birlikte çevre duyarlıı̆̆ı konularına yönelik eğitici etkinlikler düzenlemektedir. Otel ${ }_{8}$, temiz çevre ve bilgilendirme etkinliklerinde yöre halkı, tesis çalışanları ve gönüllüler ile birlikte deniz kaplumbağaları gibi nesli tehlike altındaki canlıların korunmasına yönelik eğitimler düzenlemektedir. Ayrıca kültürel ve tarihi zenginliklerin tanıtılması ve korunmasında sürdürülebilirlik uygulamaları hakkında misafirlere, tedarikçilere, yerel idarecilere ve topluma bilgi verme ve özendirme faaliyetleri yapmaktadır. Otel ${ }_{10}$ 'nun eğitim konusundaki açıklaması şöyledir:

"Sürdürülebilirlik yaklaşımının ayrılmaz bir parçası olarak değerlendirilen personellerin bilinçlendirilmesi, sürece dahil olabilmeleri için fırsatlar verilmesi ve gelişim fırsatlarına katkıda bulunabilmeleri oldukça değerlidir. Bu bağlamda yıllık eğitim planlamalarımızda ve oryantasyonlarımızda; sosyal haklar, yerel istihdamın desteklenmesi, doğal yaşamın korunması, vahşi yaşamı destekleme, yakın çevrenin tarihi turistik yerleri, kültürel zenginliği, ekolojik çeşitliliği, enerji ve su tasarrufu, çevre faaliyetleri-geri dönüşüm sistemimiz, yerel kaynaklara yönelim gibi eğitim konularımız yer almakta, işletme içerisinde sürdürülebilirlik felsefesinin yaygınlaştırılması için çalışılmaktadır."

Otel $_{17}$ ve Otel $_{31}$ ise, web sitelerinde ekoloji ve biyoçeşitlilik hakkında kapsamlı bilgiler vermekte, işletmeden kaynaklanabilecek çevre zararının yasal düzenlemeler çerçevesinde değerlendirilerek etkinin en aza indirilmesine yönelik yöntemler geliştirmektedir. Bu doğrultuda çevre yönetimi konusundaki performans ölçümleri yapılarak hedefler geliştirilmeye çalışılmaktadır. Bunun yanında hem misafirlerin hem de çalışanların çevre konusunda eğitimleri sağlanarak duyarlııklarının arttırıması hedeflenmektedir. Ayrıca Otel ${ }_{3}$, Otel $_{10}$, Otel $_{17}, \mathrm{Otel}_{26}$ ve Otel $_{31}$ istihdam konusunda özellikle yerel bölge halkına öncelik vermektedir.

\section{3. Çevre Uyumu Temasına Yönelik Uygulamalar}

Yeşil yıldız kriterleri kapsamında oluşturulan çevre uyumu temasında işletmelerin peyzaj düzenlemeleri, ağaçlandırma, yapıların doğa ile uyumu, işletme çevresindeki doğal, tarihi ve kültürel değerler ile vahşi ve evcil hayvanların ve endemik bitki türlerinin korunması gibi uygulamaların yanında oda donanımlarının ve odalarda kullanılan tüketim malzemelerinin çevreye en az zarar verecek biçimde hizmete sunulması ve bu konuda misafirlerin bilgilendirilmesi şeklinde faaliyetler bulunmaktadır (T.C. Kültür ve Turizm Bakanlığı, 2017:6). Çevre uyumu teması altında işletmelerin en fazla ekolojik çevre hakkında bilgiler verdiği ve bunu ekolojik sarf malzemeleri kullanımı ve ekolojik mimarinin takip ettiği gözlenmiştir. Çevre uyumu çerçevesinde Otel $_{11}$, Otel ${ }_{32}$ ve Otel ${ }_{3}$ işletmelerinin bilgileri şöyledir:

"Çevrede bulunan vahşi veya evcil hayvanların korunması, sağlık, bakım ve beslenmeleri ile ilgili çalışmalar yapılmaktadır. Otelimizde bulunan mini farm ile atlar, keçiler, kanatlı hayvan türleri, balıklar vb.'nin rahatça yaşayabileceği ortamları sağlamaktan mutluluk duyuyoruz. Göç sırasında yaralanmış ve bir daha uçamayacak halde bulunan layd ismini verdiğimiz leyleğimizin bakımları yapılmakta ve beslenmesi sağlanmaktadır. Tesisimizin belirli alanlarında kedi evleri 
bulunmaktadır ve bakımları, aşıları yapılmaktadır. Yaşam ve üreme alanı içerisindeki Caretta Caretta kaplumbağalarının alanları korunmaktadır. Tesiste kurumuş, hasar görmüş bitkiler "Bitki Hastanesi"'nde iyileştirilerek tekrar kullanılmaktadır. Meyve-sebze dezenfeksiyonu için doğaya zararlı klor kimyasalı yerine, ozonla dezenfeksiyonu tercih ediyoruz. Orman yangını riskine karşı, tam donanımlı itfaiye aracı bulunmaktadır." Otel ${ }_{11}$

“Kömür külü bitkiler için önemli besinler içerir. Bitkiler için en önemli besin olan fosforun en önemli mineraller, magnezyum, kalsiyum ve potasyumu bünyesinde bulundurduğundan bitkiler için güçlü bir kök sistemi oluşturmaya yardımcı olmaktadır. Aynı zamanda asidik toprağın asitliği düşürülerek toprakların iyileştirilmesinde kullanılmaktadır. Tesisimizde iş mekân bitkilerinin dikiminde kül kullanılmaktadır. Kül kullanımında; Gün içerisinde yakılan odun veya kömür külleri biriktirilmektedir. Gün sonunda biriken küller bahçe şefine teslim edilmektedir. Bahçe şefi teslim edilen külleri ekim yapmak için kullanılacak toprağa karıştırmaktadır. Kül ile karıştırılan toprak ekim yapılacak alanlarda kullanılır." Otel 32

"Doğa dostu binalar, tasarım, inşa ve işletimleri sırasında çevreye ve insan sağlığına zarar vermez. Otel bu amaçlara yönelik pek çok doğa dostu stratejiyi hayata geçirmiştir. Bunlar sürdürülebilir yerleşimler, su verimi, enerji ve atmosfer, malzemeler ve kaynaklar, iç ortam kalitesi ve tasarımda yenilikçiliktir." Otel ${ }_{3}$

Otel $_{1}$, Otel $_{18}$ ve Otel ${ }_{21}$ işletmeleri, ekolojik tasarımlarına ilişkin olarak sürdürülebilir ormancılıktan elde edilen Orman Yönetim Konseyi (FSC) sertifikasına sahip kerestelerle imal edilen ekolojik tasarımlı yataklar ile geri dönüştürülmüş şişelerden üretilen yastık ve yorganlar kullanmakta olduklarını, odalarında ekolojik etiketli duş jeli, sabun ve şampuanları kullanıma sunduklarını ve ayrıca ekolojik temizlik ürünleriyle temizlik faaliyetlerini gerçekleştirdiklerini belirtmektedirler. Otel ${ }_{32}$, işletmenin inşaat aşamasında en önem verdiği konunun doğal hayatın sürdürülebilmesi olduğunu ve arazide bulunan tek bir ağacın bile yok edilmemesi için hassasiyetle projelendirildiğini ifade etmektedir.

\subsection{Enerji ve Su Temasına Yönelik Uygulamalar}

Yeşil yıldız kriterleri çerçevesinde enerji ve su teması altında işletmelerin tasarruf sağlayıcı yeni teknolojiler kullanılarak aydınlatılması, soğutulması ve ısıtılmasının yanında güneş, hidro, rüzgâr, dalga enerjisi, jeotermal, biogaz gibi yenilenebilir enerji kaynaklarından yararlanmalarına yönelik uygulamalar bulunmaktadır (T.C. Kültür ve Turizm Bakanlığı, 2017:7). Araştırmada işletmelerin daha çok su ve elektrik tasarrufuna yönelik bilgiler verdikleri gözlenmiş, yenilenebilir enerji ve doğal gaz tasarrufu hakkında bilgi veren işletmelerin sayısının daha az olduğu belirlenmiştir. Bu doğrultuda işletmelerin çoğunun enerji ve su tasarrufuna yönelerek çevreye olan etkilerini en aza indirmeyi hedefledikleri görülmektedir. Otel ${ }_{27}$, enerji tasarrufu sağlamak amacıyla yıllık hedef belirleyerek hedef takip listesi oluşturmakta ve verileri kayıt altına almaktadır. Hedeflenen genel çevre verilerinin yanı sıra hem kişi başı su, elektrik, doğal gaz, kimyasal tüketimleri hem de departmanların hedeflenen verileri takip edilmektedir. Otel ${ }_{8}$, bir önceki yıla oranla su ve elektrik tüketiminde $\% 1$ ve doğal gaz tüketiminde $\% 2^{\prime}$ lik tasarruf hedeflediklerine dair veriler sunmaktadır.

Otel $_{11}$ ve Otel $\left.\right|_{32}$, enerji ve su tasarrufu için çalışanlara periyodik eğitimler düzenlemekte, enerji tasarruflu aydınlatmalar kullanmakta ve dış aydınlatmalarını zamanlayıcılar ile kontrol etmektedir. Bununla birlikte elektrik ve su tasarrufu için fotoselli lambalar ve musluklar kullanmaktadırlar. Bunun yanında Otel ${ }_{11}$, tesis içerisindeki birçok alanın gün ışığından yararlanarak enerji tüketimini azaltacak biçimde dizayn edildiğini ve faaliyetlerinde düşük tüketimli ekipmanlar ve sistemler tercih etmekte olduğunu ve cihazların bakımlarını belirli aralıklarla yaparak enerji kayıplarını en aza indirdiğini belirtmektedir. Ayrıca geniş alanlara sahip olan tesiste sulama sistemlerinde damlama yöntemi kullandıklarını ve peyzaj düzenlemesinde yerel flora ve floraya adapte olan bitkilerle su tüketimlerini azalttıklarını ifade etmektedir. "Sıfır Atık" belgesine sahip olduklarını belirten Otel ${ }_{17}$ ve Otel $_{31}$; enerji, su ve tüm doğal kaynakları tasarruflu bir şekilde kullandıklarını ve bu hassasiyetlerini çalışanları, misafirleri ve tedarikçileri ile paylaştıklarını belirtmektedirler. Ayrıca Otel ${ }_{8}$, Otel ${ }_{10}$, Otel ${ }_{11}$, Otel $_{17}$ ve Otel $\left.\right|_{31}$ yenilebilir enerji kullanımına yönelik güneş enerjisinden yararlanmaktadır. Otel ${ }_{10}$, saha sulama faaliyetlerini otomasyon sistemi ile yaparak hem yeraltı su kaynak kullanımını hem de elektrik enerjisi 
tüketimini azaltmayı ve böylelikle maliyet optimizasyonu sağlamayı hedeflemektedir. Bu amaç ile golf sahası içerisinde otomasyona bağlı toprak altı nem sensörleri sayesinde çimlerin ne kadar suya ihtiyacı olduğunu otomasyon sistemiyle belirleyerek sulama sistemini kullanmaktadır. Bu sistemle elektrik tüketiminin \%25 oranında azaltılmasını amaçlamıştır. Bunun sonucunda sulama sistemi ile çevre dostu ve yenilenebilir bir sistem kurularak sürekliliği olan ve dönüştürülebilir bir enerji kaynağı kullanımı sağlanmıştır. Otel ${ }_{24}$ ise gelecek dönemlerde elektrikli araçlar için tesis bünyesinde şarj istasyonları kurmayı projelendirmiştir. Ancak bu işletmenin internet sitesinde sadece bu bilgiye ulaşılmıştır. Çevre duyarlıık faaliyetlerine yönelik başka bir bilgiye rastlanmadığından analizi yapılan çevre duyarlılık bilgisine sahip 19 işletme içerisine dahil edilmemiştir.

\subsection{Kimyasallar ve Atıklar Temasına Yönelik Uygulamalar}

Yeşil yıldız kriterleri kapsamında kimyasallar ve atıklar teması altında işletmelerin çevreye duyarlı kimyasal kullanımları, yüzme havuzlarında otomatik dozaj sistemiyle ilaçlama yapılması, haşere ile mücadelede sağlığa zararsız ilaçların kullanımı veya doğal tedbirlerin alınması, artan günlük sağlıklı yiyeceklerin hayır kurumlarına verilmesi, misafirlerin ve personelin atıkları ayırabilmesinin sağlanması, tek kullanımlık ürünlerin kullanılmaması ve kullanılmış eşyaların satılması veya hayır kurumlarına bağışlanması gibi uygulamalar bulunmaktadır (T.C. Kültür ve Turizm Bakanlığı, 2017:9). Araştırmada tesislerin daha çok atık yönetimi politikasına yer verdikleri, atıkların değerlendirilmesi, kimyasalların azaltılması ve hava emisyon kontrolüne yönelik faaliyetlerin ise daha az sayıda tesis tarafından belirtildiği gözlenmiştir. Ancak çevre duyarlılığı kapsamında atık yönetiminde bilgi sunan tüm işletmelerin atıkların ayrıştırıması konusunda işletme içi faaliyetlerde bulunduğu gözlenmiştir.

Otel $_{14}$, daha az atık çıkması için dijitalleşme yatırımı yaptıklarının yanı sıra havuzlarının uluslararası standartlara göre denetlendiğini ve havuzlarında kullandıkları kimyasalların insan sağlığına zararı olmayan ve Covid-19 virüsünü etkisiz hale getiren ürünlerden oluştuğunu ifade etmektedir. Otel ${ }_{27}$, atık ayrışımı eğitimlerini düzenli ve devamlı olarak belirli aralıklarla yapmakta ve bu eğitimleri insan kaynakları biriminde kayıt altına almaktadır. Otel ${ }_{23}$, sürdürülebilir turizm için çevre dostu enerji, su harcayan ve daha az atık üreten satın almalar yapmaktadır. Ayrıca Otel ${ }_{23}$ tarafından oluşturulan dalgıç ekibi 2019 yııında daha temiz bir deniz için deniz altından yaklaşık 5 ton atık çıkarmıştır. Otel ${ }_{8}$, Otel $_{17}$ ve Otel $_{31}$, kimyasal kullanımını ve su tüketimini azaltmada yeni teknolojik donanım araçlarını kullanmaktadır. Otel $\left.\right|_{8}$, sebze ve meyve dezenfeksiyonunda ozon sisteminin kullanılmakta olduğunu ve böylelikle sudan ve kimyasaldan ciddi oranda tasarruf sağlandı̆̆ını belirtmektedir. Ayrıca havuzlarında klor yerine Gümüş-Bakır iyonizasyon sistemine geçildiğini ve bununda klor tüketimini ciddi oranda azalttığını ve böylece yosun önleyici kimyasallara da ihtiyaç duyulmadığını, bunun sonucunda da kimyasal kullanımında ciddi düşüşler yakaladıklarını belirtmektedir. Bunun yanında sistem sayesinde ters yıkama sıklığının azaltılmasıyla da su tasarrufu sağlandığını açıklamaktadır. Villa havuzlarında ise, kaya tuzundan klor üreten alternatif Tuz-Klor jeneratörlerini kullanarak kimyasal madde kullanılmadan doğal kaya tuzu sayesinde havuz dezenfeksiyonu sağlandığını ifade etmektedir. Ayrıca içme ve kullanma sularında düşük bir elektrik akımı ile zararlı bakterileri ve tüm patojenleri yok eden PotoClean sistemi kullanılarak kimyasal kullanılmadan içme suyu dezenfekte işleminin yapılmasının yanında legionella bakteri riskinin de ortadan kaldırıldığını belirtmektedir.

\subsection{Yiyecek-içecek Temasına Yönelik Uygulamalar}

Yeşil yıldız kriterleri çerçevesinde yiyecek-içecek teması altında işletmelerin gıda ve içecek üretiminden tedariğine, sunumundan atık yönetimine kadar tüm süreçlerdeki çevre duyarlılı̆ına yönelik faaliyetleri yer almaktadır. Araştırmada işletmelerin bu kapsamda daha çok gıda güvenliği hakkında bilgiler verdiği, bunu yiyecek-içecek tasarrufu, organik ürün sunma ve işletme içi üretime yönelik bilgilerin takip ettiği belirlenmiştir. Ayrıca bir işletmenin $\left(\mathrm{Otel}_{8}\right)$ tesis içerisinde gıda analiz laboratuvarı bulunmaktadır. Otel $_{1}$, Otel $_{8}$, Otel $_{11}$, Otel $_{17}$, Otel $_{18}$, Otel $_{21}$, Otel $_{31}$, Otel $_{32}$ işletmeleri yerel ürünlere özel önem vermekte ve yerel tedarikçileri desteklemektedirler. Ayrıca gıda israfının önüne geçebilmek adına uygulamalar yapmaktadırlar. Otel ${ }_{23}$, yerel ekonomiye olan katkılarının farkında olduğunu ve bu sebeple tedarikçilerinin ve hammaddelerinin $\% 95$ 'inin yerel olduğunu belirtmektedir. 
Otel $_{1}$, Otel $_{18}$ ve Otel $\left.\right|_{21}$, restoranlarında sağlıklı, dengeli ve kaliteli besinler sunabilmek için yerel ürünlerin yanında tesis içerisindeki ekim alanlarından yetiştirilen kendi ürünlerini kullanmaktadırlar. Bunun yanında kafes dışında ve açık havada yetiştirilmiş tavuklardan elde edilen yumurtaları servis etmektedirler. Ayrıca türleri tehlike altında olan balıkları serviste kullanmamaktadırlar. Otel ${ }_{32}{ }^{\prime}$ nin yiyecek ve içecek ile ilgili yaklaşımı şöyledir:

"Toprağa duyduğumuz sevgi, minnet ve doğanın bir parçası olduğumuz farkındalığıyla mevcut kaynakların verimli kullanımını ve yüksek besin değerine sahip güvenli gıda üretimini merkezimize alıyoruz. Önceliğimiz, çevreye ve misafirlerimize gereken tüm dikkat ve özeni göstermek. Üretiminin her aşamasında geleneksel ve iyi tarım uygulamalarını kullanarak organik besinler, zeytinyağları ve şaraplar elde ediyoruz. Aynı zamanda organik tohumlarımızı yetiştirdiğimiz bu başarı hikayesini sizlerle paylaşmaktan gurur ve mutluluk duyuyoruz."

Otel $_{11}$, işletmede bakılan hayvanların beslenmesinde mamanın dışında, artan ekmek ve yemeklerin israf edilmeyerek hayvanların beslenmesinde destek sağlandığını belirtmektedir.

\subsection{Diğer Hizmet ve Politikalar Temasına Yönelik Uygulamalar}

Yeşil yıldız kriterleri kapsamında diğer hizmet ve politikalar teması altında, büyük alana sahip işletmelerin işletme içi ulaşımda çevreye sera gazı vermeyen araçların kullanımı, bisiklet imkânı, faaliyetlerde en az kağıt kullanımı, çevre etiketli araçların kullanımı, yiyeceklerde yerel ve organik ürün kullanımı, yangın durumunda acil eylem planı uygulamaları, gürültü kirliliğini ortadan kaldıran uygulamalar ve çevreye duyarlı yeni teknolojilerin kullanımı gibi faaliyetler bulunmaktadır (T.C. Kültür ve Turizm Bakanlığı, 2017:10). Araştırma kapsamında özellikle yiyecek-içecek konusundaki uygulamalar bir önceki temada ayrı bir başlık altında incelemeye alınmıştır. Bunun sebebi, konaklama işletmelerinde hizmet üretiminin somut olarak gerçekleştiği en önemli uygulamaların yiyecek ve içecek üretiminde sağlanıyor olmasıdır. Diğer taraftan araştırma kapsamındaki işletmelerin diğer hizmetler teması altında çevre duyarlılık faaliyetlerinin yanında çeşitli politikalar geliştirdikleri ve bunları web sitelerinde ziyaretçilerine sundukları görülmektedir. Bu politikalardan en fazla "Çocuk Hakları" politikasının (\%47) işletmelerce uygulandığı ve bu politikanın içeriğinin çocukların korunmasının yanı sıra çocuklara yönelik çevre duyarlılığını geliştirici eğitim ve uygulamalardan oluştuğu gözlenmiştir. Bu politikayı "Kalite" (\%37) ve "Sosyal Sorumluluk" (\%37) politikalarının takip ettiği belirlenmiştir. Ayrıca bazı işletmelerin web sitesinde "Güvenli Turizm Sertifikası ve Logosu" kullanımının yanı sıra buna ilave olarak "Covid19 " politikasını da (\%42) sundukları gözlenmiştir. Otel ${ }_{23}$ 'ün çocuk hakları politikasına ilişkin açıklaması şöyledir:

"Yarının geleceği çocukların korunması için herkesin sorumluluk taşıması gerektiğine inanıyoruz. Çocuk refahının ve çocukların her çeşit zarardan korunmasının son derece önemli olduğunu ve alakalı olduğumuz tüm çocukların fiziki ve zihinsel tacizden korunmasının temel görevimiz olduğunu biliyoruz."

Otel $_{1}$, Otel ${ }_{18}$ ve Otel ${ }_{21}$, "Plant for the Planet" sloganıyla misafirlerine havluları tekrar kullanmaya teşvik etmektedir. Sağlanan enerji ve su tasarrufu ile ağaç dikimini finanse ettiğini belirtmektedir. Otel ${ }_{8}$, Otel $_{11}$, Otel $_{17}$, Otel $_{31}$ ve Otel ${ }_{32}$, yerel ve turizm yöneticilerinin yer aldığı organizasyonlar düzenleyerek özel ve resmi günlerde kültür turizminin artması ve yabancı turistlere tanıtımı için çalışmalar yapmaktadır. Ayrıca Otel ${ }_{8}$, akıllı oda teknolojileri sayesinde mobil telefonlar üzerinden oda kapılarının açılması, oda klima ve ışık kontrollerinin sağlanması, kapı panelinde DND (Don't Disturb) göstergesinin kullanımı gibi imkânlar sağlamaktadır. Otel ${ }_{11}$, çalışanlarına yangın eğitimi vermekte ve tatbikatlar yapmaktadır. Bunun yanında down sendromlu kişilere işletme içinde çalışma imkânı tanıyarak günlük yaşamla bütünleşme olanağı sağlamaktadır. Otel ${ }_{17}$ ve Otel $_{31}$, kadınların iş gücüne katılımını tüm departmanlarında desteklemekte, cinsiyet ayrımcılığı yapmadan eşit işe eşit ücret politikası uygulamakta, kariyer fırsatlarından eşit faydalanılmasını sağlayarak yönetimde kadınların yer almasını desteklemektedir. 


\section{Sonuç ve Öneriler}

Günümüz dünyasında birçok kurum ve kuruluş tarafından çevrenin korunması ve sürdürülebilir olması adına çalışmalar yapılmaktadır. Bunun yanında çok sayıdaki konaklama işletmesi çevre koruma konusundaki farkındalıkları otel politikalarına da yansıtmaktadır. Bununla birlikte konaklama işletmeleri çevre duyarlıığı faaliyetlerine katılarak rekabet üstünlüğü de elde edebilmektedirler. Konaklama işletmelerinin yanı sıra turistler de konaklayacakları işletmenin çevreye duyarlı çalışmalarını önemsemektedirler. Örneğin sürdürülebilirliğe erişimde kararlıık gösteren turizm işletmeleri için öncü bir yönetim, eğitim ve sertifikasyon girişimi olan Travelife web sitesinde çevreci uygulamaları olan otellerin listesi potansiyel turistlere sunulmakta ve yine aynı amaçla birçok konaklama işletmesi çevre politikalarını ve uygulamalarını web sitelerinde sunmaktadırlar (Travelife, 2021).

Bu çalışmada 2019 yılında QM Kalite Yönetim Ödülü alan toplam 32 konaklama işletmesinin yeşil yıldız kriterleri kapsamında çevre duyarlılığı konusundaki Genel Yönetim, Eğitim, Çevre Uyumu, Enerji ve Su, Kimyasallar ve Atıklar, Yiyecek-içecek ile Diğer Hizmetler ve Politikalar şeklindeki yedi ana kritere yönelik faaliyetleri incelenmiştir. Çalışma kapsamındaki 32 konaklama işletmesinin web sitelerinin analizinden elde edilen bulgular doğrultusunda işletmelerin web sitelerinde \%60 oranda çevre duyarlıık bilgilerinin olduğu ve bu işletmelerin \%74'nünün çevre politikasına sahip olduğu saptanmıştır. Buna göre işletmelerin çoğunun çevreyi koruma konusunda bilinçli oldukları ve politikalarını da bu doğrultuda oluşturdukları görülmektedir. Ancak \%65 oranla 21 işletmenin Yeşil Yıldız sertifikasına sahip olmasına rağmen bu işletmelerden \%52 oranla sadece 11 işletmenin web sitesinde Yeşil Yıldız sertifika veya logosuna yer verdiği gözlenmiştir. Ayrıca \%12 oranla dört işletmenin web sitelerinde sadece ödül, logo veya sertifika bilgisine yer verdikleri belirlenmiştir. Örneğin Otel ${ }_{7}$ işletmesi Yeşil Yıldız belgesine sahip olmasına rağmen web sitesinde çevre politikasına yer vermemiştir. Bunun gibi eksiklerin giderilmesinde işletmelerin web sitelerinde çevre duyarlıı̆ı uygulamalarına ilişkin daha kapsamlı bilgiler sunması önerilir. Böylelikle turizm hareketlerine katılanların bu bilgilere ulaşmasıyla işletmelerin talep edilmesi yönünde avantaj sağlanabileceği düşünülmektedir.

Uluslararası boyutta çevrenin korunmasına yönelik girişimleri destekleyerek sürdürülebilir turizme katkı sağlamayı amaçlayan Yeşil Anahtar Ödülü uygulaması Türkiye'de TÜRÇEV (Türkiye Çevre Eğitim Vakfı) tarafınca yürütülmektedir. Araştırma kapsamındaki web sitelerinde 32 işletmeden 21 tesisin Yeşil Yıldız sertifikasına sahip olduğu görülürken sadece bir işletmenin Yeşil Anahtar sertifikasına sahip olduğu belirlenmiştir. Bu bağlamda QM Kalite Yönetim Ödülü alan işletmelerin Yeşil Anahtar sertifikasını da elde etmeleri teşvik edilmelidir. Ayrıca araştırma kapsamında incelemeye alınan QM Kalite Yönetim Ödül kategorileri içerisine çevre duyarlılığı konusunda da ödül kategorilerinin dâhil edilmesinin turizm işletmelerindeki çevre duyarlılı̆ını daha da arttırabileceği düşünülmektedir. Diğer taraftan 2021 yılına ilişkin ülkemizdeki Yeşil Yıldız ve Yeşil Anahtar sertifikalarına sahip tesis sayıları incelendiğinde Yeşil Anahtar sertifikasına sahip tesis sayılarının (93 tesis) Yeşil Yıldız sertifikasına sahip olan tesislerden (457 tesis) \%80 oranında daha az sayıda olduğu görülmektedir (TÜRÇEV, 2021). Bu bağlamda Yeşil Yıldız uygulamasında sunulan teşviklerin Yeşil Anahtar için de uygulanmasıyla hem çevre bilincinin arttırılması hem de bu konunun uluslararası boyuta daha güçlü bir biçimde taşınması sağlanabilecektir.

Araştırma kapsamında zincir konaklama işletmelerinin web sitelerinde çevre duyarlılığı konularına daha fazla yer verdikleri gözlenmiştir. Çevre duyarlılık bilgisine sahip 19 işletmeden üç tanesi bağımsız, diğerleri zincir işletmelerdendir. Ayrıca sürdürülebilirlik raporuna sahip 11 işletmenin on tanesi zincir işletmelerdendir, biri ise bağımsız işletmedir. Araştırmada incelenen kalite yönetim ödülü alan toplam 32 işletmenin ise \%72 oranında zincir işletmelerden oluştuğu belirlenmiştir. Bununla birlikte Ertaş ve arkadaşlarının 2017 yılında konaklama işletmelerinin çevre duyarlıı̆̆ına yönelik yaptıkları araştırmasında zincir konaklama işletmelerinin çevre duyarlıığı konusunda bağımsız işletmelere göre daha fazla faaliyetlerde bulundukları gözlenmiştir (Ertaş ve diğerleri, 2017). Bu araştırmada da zincir konaklama işletmelerinin daha fazla çevreye duyarlı uygulamalar gerçekleştirdikleri saptanmıştır. Bu bağlamda bağımsız konaklama işletmeleriyle birlikte küçük ve orta ölçekli konaklama işletmelerinin de çevreye duyarlı faaliyetlerinin artmasında teşvik edici uygulamaların yürürlüğe alınması önerilmektedir. 
Çevrenin korunması ve sürdürülebilir turizmin sağlanması için ön koşul çevre bilincinin oluşmasıdır. Çevre bilincinin oluşması da eğitim yolu ile sağlanmaktadır. Çalışmada çevre bilincinin oluşturulması amacı ile işletmelerce eğitimler verildiği gözlenmiştir. Araştırma kapsamındaki işletmelerin eğitim faaliyetleri ele alındığında; personel eğitimi \%68, misafir eğitimi \%26, tedarikçi eğitimi \%21 olarak saptanmıştır. Burada genelde personel eğitimi ile nitelikli personele sahip olmada işletmelerin uygulamalar yaptığı görülürken misafir ve tedarikçi eğitim faaliyetlerinin düşük seviyede olduğu gözlenmiştir. Buradan hareketle çevre bilincinin arttırılması için eğitimlerin misafirlere ve tüm paydaşlara net ve anlaşılır verilmesinin sürdürülebilir çevre açısından fayda sağlayacağı düşünülmektedir. İncelemeye alınan işletmelerin çevre uyumu konusunda \%47 oranla en fazla ekolojik çevre hakkında bilgiler sunduğu ve bunu \%37 oranla ekolojik sarf malzeme kullanımı ve \%21 oranla ekolojik mimari bilgilerinin takip ettiği belirlenmiştir. Konaklama işletmelerinin çevre duyarlıık faaliyetleri bütüncül olarak ele alındığında çevre faaliyetlerinin en etkin bir biçimde uygulanabilmesinin ekolojik mimari ile bütünleşerek sağlanabileceği düşünülmektedir. Bu doğrultuda tesislerin inşa ve yenilemelerinde ekolojik mimariyi hassasiyetle gözeterek projelendirilmeleri önerilmektedir.

Araştırma kapsamında yenilenebilir enerji kullanan işletmelerin \%26 oranında olduğu tespit edilmiştir. $\mathrm{Bu}$ bağlamda yenilenebilir enerji kullanımına önem veren çevre bilincine sahip olan konaklama işletmelerinin sayısının arttırılması önerilmektedir. Konaklama işletmelerinin \%68'inde su tasarrufu uygulamalarının olduğu belirlenirken, yerel çevreye ilişkin olarak yöresel farkındalık politikasına sahip işletmelerin \%21 oranında olduğu sonucuna varılmıştır. Buna bağlı olarak işletmelerin çevre duyarlılı̆ına yönelik yöre halkı ile daha fazla iş birliği sağlamaları önerilmektedir. Bunun yanında özellikle sürdürülebilirlik raporlarını web sitelerinde sunan konaklama işletmelerinin ilgili raporlarda; enerji ve su tasarrufu sağlamada, kimyasalların kullanımını ve atıkları azaltmada yeni teknolojileri faaliyetlerinde kullandıkları saptanmıştır. Ayrıca işletmelerin web sitelerinde sundukları hijyen broşürleri ve manifestolarında Covid-19 kapsamında hizmet üretiminde alınan tedbirlere yönelik temassız teknolojileri kısa sürede hayata geçirdiklerine ilişkin bilgilere yer verdikleri de gözlenmiştir. İşletmelerin rekabet üstünlüğü yaratarak daha fazla tercih edilmelerini sağlamada çevreye duyarlı uygulamalarının yanında çalışmalarını sürdürülebilirlik raporlarıyla sunmaları ve bu tür yeni teknolojileri faaliyetlerinde kullanmaları da önerilmektedir.

Yeşil Yıldız uygulamasında atık su yönetimi diğer tüm çevre politikaları gibi önemli bir yer tutmaktadır. Araştırmada işletmelerin \%34'ünde Yeşil Yıldız ve Mavi Bayrak uygulamalarının eşit oranda olduğu sonucuna varılmıştır. Varılan bu sonuç bağlamında deniz suyu temizliğini önemseyen ve atık su politikası olan Mavi Bayrak uygulamasının Yeşil Yıldız uygulamasını desteklediği sonucuna varıımıştır. Kuşkusuz çevreyi korumaya yönelik olan tüm uygulamalar (Yeşil Yıldız, Mavi Bayrak, ISO 14001 vb.) sürdürülebilir turizm açısından büyük öneme sahiptir. Çevreye duyarlı uygulamaların işletmeler tarafından kullanılması ve bir politika haline getirilmesi için birtakım yaptırımların uygulanmasının, yasa çıkarılmasının veya bu uygulamaları yerine getiren işletmelere teşvik verilmesinin çevreci anlayış bilincinin yaygınlaşmasında yardımcı olacağı düşünülmektedir. Böylelikle uluslararası boyutta Mavi Bayrak konusunda 2021 yılı itibariyle üçüncü sırada güçlü bir konumda olan ülkemizin bu konumunu koruyarak daha üst sıralara çıkabilmesi sağlanabilecektir. Bunun yanında sembolik de olsa çevreci uygulamalara önem vererek sürdüren işletmelere ödüller verilmesi çevre bilincini pekiştirecektir. Araştırma kapsamındaki konaklama işletmelerinin web sitelerinde yer alan çevre duyarlıık faaliyetlerine ilişkin olarak sunulan dilin en fazla Türkçe ve İngilizce dillerinde olduğu gözlenmiştir. Buna bağlı olarak konaklama işletmelerinin çevreye duyarlı faaliyetlerine ilişkin web sitelerinde ülkemizi en fazla ziyaret eden pazarlara (Alman, Rus, Arap pazarları gibi) yönelik olarak diğer dillerde de çevre bilgilerine yer vermeleri önem taşımaktadır. Diğer yandan sağlıklı bireyler kadar yerli ve yabancı tüm engelli bireylerin de kaliteli hizmet anlayışına sahip konaklama tesislerine erişim hakkı bulunmaktadır. Bu sebeple konaklama işletmelerine engelli misafirlere ilişkin erişim olanaklarını kapsayan ayrı politikalar oluşturmaları ve bu uygulamalarını da çeşitli dillerde web sitelerinde sunmaları önerilmektedir.

Çevreye duyarlı belge olarak verilen Yeşil Yıldızın tanıtımında birtakım sorunlar vardır, bu sorunlar çekici bir unsur olarak pazarlanması kısmıdır. Çözüm olarak Yeşil Yıldız hakkında Kültür ve Turizm Bakanlığı'nın, sivil toplum kuruluşları iş birliği ile Türkiye çapında toplantı ve tanıtımlar yapması faydalı 
olacaktır. Bu toplantı ve tanıtımlarda konaklama işletmeleri ve toplumun, çevreye karşı duyarlı olmaları konusundaki görev ve sorumluluklarının olduğu konusunda ikna edici bir yolun izlenmesi önem arz etmektedir. Yeşil Yıldız projesi uygulamasının temel amacı, konaklama işletmelerini ve toplumu çevre duyarlıı̆ı konusunda teşvik edip yönlendirmek ve aynı zamanda zararlı atık miktarını en aza indirmek veya tamamen ortadan kaldırmak, geri dönüşüm ve yenilenebilir enerji kaynaklarının kullanımını teşvik etmek, doğal kaynak tüketiminde tasarrufa yönlendirmek gibi uygulamalardır (Özçoban, 2010:214). Yeşil Yıldız uygulamalarını yerine getiren konaklama işletmelerine teşvik amaçlı olarak daha önceki dönemlerde elektrik indirim desteği verilmekteydi ve bu teşvik ile birçok konaklama işletmesinin Yeşil Yıldız projesine katılımı sağlanmıştır. Ancak elektrik indirim desteğinin geri çekilmesi konaklama işletmeleri açısından Yeşil Yıldız uygulamasını olumsuz yönde etkilemektedir. Yeni dönemler için devletin elektrik indirim desteği gibi teşvik programlarını sürdürmeleri ve konaklama işletmelerinin Yeşil Yıldız projesine katılımını sağlamaları gerekmektedir (Yıldırım, 2019:50). Devlet tarafından çevreci uygulamaları olan otellere yeşil turizm hareketlerine ilişkin teşviklerin verilmeye devam etmesinin ve ödüller verilmesinin çevre bilincinin oluşması ve geliştirilmesi yönünde sürdürülebilir turizm açısından fayda sağlayacağı düşünülmektedir. Ayrıca gelecek dönemlerdeki benzer araştırmaların farklı tesisler ve bölgeler seçilerek incelenmesiyle çevre duyarlılığı konusundaki yeni uygulamaların literatüre kazandırılması sağlanabilecektir.

\section{Teşekkür ve Bilgi Notu}

Makalede araştırma ve yayın etiğine uyulmuştur. Çalışmada etik kurul izni gerekmemiştir.

\section{Yazar Katkısı ve Çıkar Çatışması Beyan Bilgisi}

Makalede tüm yazarlar aynı oranda katkıda bulunmuştur. Herhangi bir çıkar çatışması bulunmamaktadır.

\section{Kaynaklar}

Baltacı, A. (2018). Nitel Araştırmalarda Örnekleme Yöntemleri ve Örnek Hacmi Sorunsalı Üzerine Kavramsal Bir İnceleme. Bitlis Eren Üniversitesi Sosyal Bilimler Enstitüsü Dergisi, 7(1), 231-274.

Berg, B. L. ve Lune, H. (2019). Sosyal Bilimlerde Nitel Araştırma Yöntemleri. Çev. Aydın, H. Eğitim Yayınevi, İstanbul.

Beşkese, A. (2001). Ulusal Kalite Ödülü İçin Alternatif Bir Model Önerisi (Doktora Tezi). İstanbul Teknik Üniversitesi, Fen Bilimleri Enstitüsü, İstanbul.

Booking.com (2021). Booking.com's 2021 Sustainable Travel Report. Erişim Adresi (12.07.2021): https://news.booking.com/bookingcoms-2021-sustainable-travel-report-indicates-potentialwatershed-moment-for-industry-and-consumers-gb/

Corredor, P. ve Goni, S. (2010). Quality awards and performance: is there a relationship? The TQM Journal, 22(5), 529-538.

Cömert, M. ve Özata Şahin, E. (2016). Sürdürülebilir Turizm Kapsamında Yeşil Yıldız Çevreye Duyarlılık Projesi. Uluslararası Sosyal Araştırmalar Dergisi. 9(47), 1169-1178

Doğan, Ö. ve Ertaş, F. C. (2018). Çevreye Duyarlılı̆ı̆n Rekabet Gücüne Etkisi: Yeşil Yıldızlı Oteller Üzerine Bir Uygulama. Maliye ve Finans Yazıları Dergisi. 110, 217-234

Ekergil, V. ve Özgür Göde, M. (2017). Küresel Raporlama Girişimi (GRI) Standartlarına Göre Seçilen Otellerin Sürdürülebilirlik Raporlarının Analizi ve Değerlendirilmesi. Business and Economics Research Journal, 8(4), 859-871.

Ertaş, M., Kırlar C. B., Yeşilyurt, H. ve Koçak, N. (2017). Konaklama işletmelerinin Yeşil Yıldız Uygulamaları Kapsamında Çevreye Duyarlılığıın Değerlendirilmesi. Seyahat ve Otel Işletmeciliği Dergisi, 15(1), 102-119.

Güneş, S. G. (2020). Sorumlu Turizm. S. G. Güneş \& S. Özdemir Akgül (Ed.). Sorumlu Turizm. Nobel Akademik Yayıncılık (Ekim 2020), 1. Basım. Bölüm 1. (s. 3-38). ISBN: 978-625-406-568-2. Ankara: Nobel Yayınevi. 
Mesci, Z. (2014). Otellerin Çevreci Uygulamalarının Değerlendirilmesi: Yeşil Yıldızlı Bir Otel İşletmesinde Örnek Olay Çalışması. Seyahat ve Otel Işsletmeciliği Dergisi. 11 (1), 90-102.

Nemli, E. (2011). Çevreye Duyarlı Yönetim Anlayışı. İstanbul Üniversitesi Siyasal Bilgiler Fakültesi Dergisi. (23-24), 211-224.

Özçoban, E. (2010). Türkiye'de Turizm Endüstrisinde Sosyal Sorumluluk Kampanyaları: T.C Kültür ve Turizm Bakanlığı'nın Yeşil Yıldız Uygulaması ve Calista Otel Örneği Üzerine Amprik Bir Çalışma, (Yayımlanmamış Yüksek Lisans Tezi). Ankara Üniversitesi Sosyal Bilimler Enstitüsü, Ankara.

Patton, M. Q. (2014). Nitel araştırma ve değerlendirme yöntemleri. Çev. M. Bütün, \& S. B. Demir Pegem Akademi Yayıncılık, Ankara.

Samanlı, M. (2009). Kalite Ödüllerinin Şirket Performansına Etkisi: Türkiye Özelinde TÜSiAD-KALDER Ulusal Kalite Ödülü Örneği (Yüksek Lisans Tezi). İstanbul Teknik Üniversitesi Fen Bilimleri Enstitüsü, İstanbul.

QM Awards. (2019). Türk Turizminin Enleri Qm Awards 2019'da Ödülle Taçlandı. Erişim Adresi (13.07.2021): https://www.qmawards.com/tr/2019-basin-bulteni/

QM Awards. (2021). QM Awards Nedir?. Erişim Adresi (13.07.2021): https://www.qmawards.com/tr/2020-qm-awards-nedir/\#

Travelife. (2021). Sustainability in Tourism. Erişim Adresi (16.07.2021): https://www.travelife.info/index_new.php?menu=home\&lang=tr\#

Turizm Gazetesi. (2021). Turizm Gazetesi: Ver Parayı Al Ödülü. Erişim Adresi (06.02.2021): https://www.turizmgazetesi.com/haber/ver-parayi-al-odulu/80376

TÜRÇEV. (2021). Yeşil Anahtar Ödüllü Tesisler. Erişim Adresi (14.07.2021): http://www.turcev.org.tr/v2/icerikdetay.aspx?icerik_id=31

T.C. Kültür ve Turizm Bakanlığı. (2017). Çevreye Duyarlı Konaklama Tesisleri için Sınıflandırma Formu. Erişim Adresi (02.06.2021): http://www.koder.org.tr/PDF/uyePDFler/tr-yesil-yildizsiniflandirma-formu.pdf

T.C. Kültür ve Turizm Bakanlığı. (2021a). Yatırım ve İşletmeler Genel Müdürlüğü: Çevreye Duyarlıık Kampanyası (Yeşil Yıldız). Erişim Adresi (04.07.2021): https://yigm.ktb.gov.tr/TR11596/cevreye-duyarlilik-kampanyasi-yesil-yildiz.html

T.C. Kültür ve Turizm Bakanlığı. (2021b). Yatırım ve İşletmeler Genel Müdürlüğ̈̈: Turizm Tesisleri. Erişim Adresi (06.06.2021): https://yigm.ktb.gov.tr/Eklenti/81131,tib-04032021xls.xls?0

Ünlüönen, K. Kızanlıklı, M.M. ve Arslan, E. (2011). Otel İşletmelerindeki Eko-Etiket ve Sistem Yönetim Belgelerinin Belirlenmesine Yönelik Bir Araştırma. 12. Ulusal Turizm Kongresi, 30 Kasım-4 Aralık Düzce, s. 446-457.

UNWTO. (2021). UNWTO: International Tourism Highlights, 2020 Edition. Erişim Adresi (24.05.2021): https://www.e-unwto.org/doi/epdf/10.18111/9789284422456

Yıldırım, A. ve Şimşek, H. (2011). Sosyal Bilimlerde Nitel Araştırma Yöntemleri. 8. Basım, Ankara: Seçkin Yayıncilık.

Yıldırım, Ö. (2019). İstanbul'da Beş Yıldızlı Otellerde Yeşil Yıldız Uygulamasının Otellerin İşletmeciliğine Sağladığı Avantajların Analizi (Yayımlanmamış Yüksek Lisans Tezi). İstanbul Ticaret Üniversitesi, İstanbul

Yurtlu, M. (2021). Current Cloud-Based Software Services Used in Online Marketing of Hotels in Turkey. Yaşar Üniversitesi E-Dergisi, 16, 51-68. 